Volume 10 Issue 3, July-September 2016: pp. 413-. Copyright (c) 2015-2016 FIAT JUSTISIA. Faculty of Law, Lampung University, Bandarlampung, Lampung, Indonesia. ISSN: 1978-5186 | e-ISSN: 2477-6238.

Open Access: http://jurnal.fh.unila.ac.id/index.php/fiat

Fiat Justisia is licensed under a Creative Commons Attribution 4.0 International License, which permits unrestricted use, distribution, and reproduction in any medium, provided the original work is properly cited.

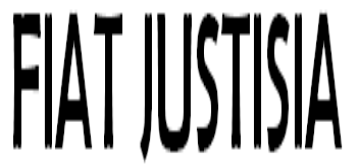

\title{
STATUS HUKUM PERALIHAN HAK ATAS TANAH YANG DIPEROLEH DARI LELANG BERDASARKAN HAK MENDAHULU NEGARA
}

\section{Legal Status of the Transfer of Land was obtained from Auction Based Country's Precedence Rights}

\author{
Kurnia Martini Dwi Putri A.T. \\ Badan Pertanahan Nasional Kota Bandarlampung \\ email: niamartini3110@gmail.com
}

\begin{abstract}
Tax is one of the biggest fund sources proponents in Indonesia's development activities. Tax payment is an obligation for every Tax Subject. They would be reputed to have the debt to Country once they don't pay the tax. Tax liability is a debt that particularly arises because of law, so it has the precedence characteristic over other debts. If a Taxpayer doesn't pay their tax, Government can sell their valuable assets of by the auction based on State Precedence Rights. In Bandar Lampung City, land title transfer registration that is obtained by auction based on Country's Precedence Right happened to the ownership land of a personal property on behalf of individual belonging, which became a company's tax liability payment, and also an object of an inheritance dispute. The land title transfer registration validity then became legally questionable, because the auction object is recorded on behalf of individual ownership, not the Companies. Moreover, it was under inheritance dispute and has been blockaded at The Bandar Lampung Land Affair Office.
\end{abstract}

Keywords: Country's Precedence Rights, Auction, Land Certificate Blockage

\begin{abstract}
Abstrak
Pajak merupakan salah satu pendukung sumber dana terbesar dalam kegiatan pembangunan Indonesia. Pembayaran pajak merupakan kewajiban bagi setiap Subyek Pajak. Mereka akan dikenal memiliki utang kepada Negara
\end{abstract}


setelah mereka tidak membayar pajak. Kewajiban pajak adalah utang yang sangat timbul karena hukum, sehingga memiliki karakteristik didahulukan dari hutang lainnya. Apabila Wajib Pajak tidak membayar pajak mereka, Pemerintah dapat menjual hasil aset yang bernilai tinggi oleh yang berdasarkan Hak Mendahulu Negara. Di Kota Bandar Lampung, pendaftaran tanah judul transfer yang diperoleh dengan lelang berdasarkan Hak Mendahulu Negara terjadi tanah kepemilikan properti pribadi atas nama pribadi milik, yang menjadi pembayaran kewajiban pajak perusahaan, dan juga obyek sengketa warisan. Judul tanah validitas pendaftaran pengalihan kemudian menjadi hukum dipertanyakan, karena objek lelang dicatat atas nama kepemilikan individu, bukan perusahaan. Selain itu, di bawah sengketa warisan dan telah diblokade di Kantor Pertanahan Bandar Lampung.

Kata Kunci: Hak Mendahulu Negara, Lelang, Pemblokiran Sertifikat Tanah

\section{A. Pendahuluan}

Perkembangan zaman menuntut adanya keserasian dalam pembangunan dari suatu negara. Pembangunan berkaitan langsung dengan penyediaan sarana dan prasarana untuk kemaslahatan hidup masyarakat di suatu negara. Semakin baik dan terpenuhinya kebutuhan masyarakat lewat sarana dan prasarana yang disediakan oleh negara, diharapkan semakin sejahteralah masyarakat itu.

Pembangunan tentunya membutuhkan biaya yang tidak sedikit. Indonesia merupakan negara kepulauan yang memerlukan pembangunan sarana dan prasarana khusus, tergantung kebutuhan tiap-tiap daerah. Salah satu sumber dana penyokong kegiatan pembangunan paling besar di Indonesia adalah pajak. Hal ini dapat dilihat dari Penjelasan Umum Atas UU No. 14 Tahun 2015 tentang Anggaran Pendapatan dan Belanja Negara Tahun Anggaran 2016, yang berisi: "Agar prioritas sasaran pembangunan nasional dan prioritas lainnya tersebut dapat tercapai, salah satu hal yang perlu dilakukan pemerintah adalah mengoptimalkan Penerimaan Perpajakan dan PNBP."

Salah satu karakteristik pokok dari pajak adalah bahwa pemungutannya harus berdasarkan undang-undang. Hal ini disebabkan karena pada hakekatnya pajak adalah beban yang harus dipikul oleh rakyat banyak, sehingga dalam perumusan macam, jenis dan berat rintangannya tarif pajak itu, rakyat harus ikut serta menentukan dan menyetujuinya, melalui wakil-wakilnya di Parlemen atau Dewan Perwakilan Rakyat. ${ }^{1}$

Berdasarkan Pasal 1 ayat (1) Undang-Undang No. 28 Tahun 2007 tentang Perubahan Ketiga atas Undang-Undang No. 6 Tahun 1983 tentang

\footnotetext{
${ }^{1}$ Nurmantu, Safri. (2005). Pengantar Perpajakan. Jakarta: Granit, p. 14.
} 
Ketentuan Umum dan Tata Cara Perpajakan, yang selanjutnya akan disebut UU KUP, yang dimaksud dengan pajak adalah kontribusi wajib kepada negara yang terutang oleh orang pribadi atau badan yang bersifat memaksa berdasarkan undang-undang dengan cara tidak mendapatkan imbalan secara langsung dan digunakan untuk keperluan negara bagi sebesar-besarnya kemakmuran rakyat.

Pajak dibedakan menjadi dua berdasarkan kewenangan memungut dan mengelolanya, menjadi pajak pusat dan pajak daerah. Pajak pusat atau pajak negara adalah pajak yang dikelola oleh pemerintah pusat (Direktorat Jenderal Pajak) dan hasilnya dipergunakan untuk membiayai pengeluaran rutin negara dan pembangunan (APBN). Contohnya: PPh, PPN/PPn.BM, PBB, dan Bea Materai. Pajak daerah adalah pajak yang dikelola oleh pemerintah daerah Tk. I dan II dan hasilnya dipergunakan untuk membiayai pengeluaran rutin dan pembangunan daerah (APBD). Contohnya: Pajak Pembangunan I, Pajak Reklame, Pajak Bangsa Asing (PBA), dan Pajak Kendaraan Bermotor. ${ }^{2}$

Pembayaran pajak merupakan suatu kewajiban bagi setiap subjek pajak. Namun pada kenyataannya, sering terjadi subjek pajak menunggak pembayaran pajak, sehingga subjek pajak dianggap berutang pada negara untuk melunasi pembayaran pajaknya tersebut.

Utang pajak adalah utang yang timbulnya secara khusus, karena negara (kreditur) terikat dan tidak dapat memilih secara bebas siapa yang akan dijadikan debiturnya, seperti dalam hukum perdata. Hal ini terjadi karena utang pajak timbul karena undang-undang. ${ }^{3}$ Dampak timbulnya utang pajak karena undang-undang, mengakibatkan ia bersifat mendahulu dari utang-utang lainnya

Pasal 21 ayat (3) butir a UU KUP mengatur bahwa, "Dalam hal wajib pajak dinyatakan pailit, bubar atau dilikuidasi maka kurator, likuidator, atau orang atau badan yang ditugasi untuk melakukan pemberesan dilarang membagikan harta wajib pajak dalam pailit, pembubaran, atau likuidasi kepada pemegang saham atau kreditur lainnya sebelum menggunakan harta tersebut untuk membayar pajak wajib pajak tersebut."

Penagihan utang pajak ialah serangkaian tindakan agar penunggak pajak melunasi utang pajak dan biaya penagihan pajak, yang dilakukan dengan menerbitkan: ${ }^{4}$

\footnotetext{
${ }^{2}$ Marsyahrul, Tony. (2005). Pengantar Perpajakan. Jakarta: PT. Gramedia Widiasarana Indonesia, p. 5.

${ }^{3}$ Soemitro, Rochmat. (1998). Asas dan Dasar Perpajakan 2. Bandung: PT. Refika Aditama, p. 2.

${ }^{4}$ Sutedi, Adrian. (2013). Hukum Pajak. Jakarta: PT. Sinar Grafika, p. 48-49.
} 
1. Surat Teguran, setelah melampaui tujuh hari sejak saat jatuh tempo dari Surat Tagihan Pajak (STP)/ Surat Ketetapan Pajak Kurang Bayar (SKPKB)/ Surat Ketetapan Pajak Kurang Bayar Tambahan (SKPKBT).

2. Penagihan Seketika dan Sekaligus, jika terjadi suatu peristiwa atau keadaan mendesak yang menyebabkan utang pajak tidak tertagih, aparatur perpajakan diberi kewenangan untuk melakukan penagihan seketika dan sekaligus,

3. Surat Paksa, dikeluarkan apabila wajib pajak tidak melunasi utang pajaknya dalam waktu 21 (dua puluh satu) hari setelah dikeluarkan surat teguran.

4. Penyitaan, dilaksanakan oleh juru sita apabila $2 \times 24$ jam sejak tanggal surat paksa diberitahukan kepada wajib pajak. Penyitaan dapat dilakukan terhadap barang bergerak atau tidak bergerak.

5. Lelang, dapat dilaksanakan terhadap barang milik wajib pajak setelah 14 (empat belas) hari sejak pelaksanaan penyitaan. Penjualan secara lelang dilakukan melalui Kantor Lelang Negara.

Serangkaian tindakan penagihan tersebut mempunyai jangka waktu yang panjang, sehingga wajib pajak diberikan waktu untuk melunasi utang pajaknya pada negara. Apabila yang bersangkutan tetap belum dapat melunasi utang pajaknya tersebut, maka pemerintah dapat melelang aset-aset dari wajib pajak itu. Aset-aset wajib pajak yang dilelang karena menunggak utang pajak penghasilan ialah aset yang berharga, dapat berupa barang bergerak maupun tidak bergerak, misalnya tanah.

Tanah merupakan suatu hal yang sangat penting bagi masyarakat Indonesia. Dari sisi sosial dan ekonomis, peran tanah bagi masyarakat sangat tinggi. Segala aspek kegiatan manusia selalu berkaitan dengan tanah, mulai dari untuk tempat tinggal, tempat mencari nafkah, sebagai suatu harta yang dapat diwariskan, dan dapat menjadi penentu status seseorang dalam masyarakat.

Berbicara mengenai tanah, maka akan berbicara juga mengenai lembaga pemerintah yang bertugas mengurus perihal pertanahan di Indonesia. Badan Pertanahan Nasional Republik Indonesia yang saat ini telah berganti nama menjadi Kementerian Agraria dan Tata Ruang adalah suatu instansi pemerintah yang bergerak di bidang pertanahan, yang melaksanakan tugas-tugas berkaitan dengan tanah.

Pasal 19 Undang-undang Nomor 5 Tahun 1960 tentang Peraturan Dasar Pokok-pokok Agraria (UUPA) menetapkan bahwa untuk menjamin kepastian hukum oleh Pemerintah diadakan pendaftaran tanah di seluruh wilayah Republik Indonesia.

Semakin berkembangnya zaman, jumlah populasi manusia terus meningkat. Artinya, kebutuhan atas tanah oleh tiap-tiap individu makin bertambah pula, padahal kondisi dan keadaan tanah adalah tetap, tidak 
bertambah. Oleh karena besarnya arti dari suatu tanah tersebut, maka masyarakat membutuhkan suatu jaminan kepastian hukum terhadap hak-hak mereka akan tanah.

Boedi Harsono berpendapat bahwa dengan bertambah majunya perekonomian rakyat dan perekonomian nasional kita, bertambah pula keperluan akan kepastian mengenai soal-soal yang bersangkutan dengan kegiatan-kegiatan ekonomi itu. Tanah rakyat semakin lama semakin banyak tersangkut dalam kegiatan-kegiatan tersebut, misalnya dalam jual beli, sewa menyewa, pemberian kredit dan lain-lainnya. Berhubung dengan itulah, semakin lama semakin terasa pula perlu adanya jaminan kepastian hukum dan kepastian hak di bidang pertanahan. ${ }^{5}$

Jaminan kepastian hukum tersebut kemudian diwujudkan dalam bentuk sertipikat hak atas tanah. Sertipikat tanah adalah dokumen resmi salinan buku tanah yang berisi bukti pemilikan/penguasaan hak atas tanah, yang menjelaskan dengan detail bentuk, letak, luas, batas-batas bidang tanah, dan sebagainya.

Kepastian hukum atas objek tanah (letak, luas, dan batas) serta kepastian subjek, merupakan syarat pokok untuk mendapatkan perlindungan hukum hak atas pemilikan tanah. Hak atas sebidang tanah yang sudah terdaftar dan memperoleh sertipikat, mendapat perlindungan justisiabel dari tindakan sewenang-wenang. Perlindungan hukum itu sendiri merupakan upaya berdasarkan hukum, baik preventif maupun represif, agar sertipikat sebagai tanda bukti hak tanah yang kuat memperoleh perlindungan hukum. ${ }^{6}$

Bentuk perlindungan hukum pemerintah di bidang pertanahan ialah adanya suatu kewajiban untuk melaksanakan pendaftaran tanah. Terkait dengan pelelangan tanah untuk pelunasan utang pajak berdasarkan hak mendahulu negara, maka wajib ditindaklanjuti dengan melaksanakan pendaftaran tanah. Pendaftaran tanah diselenggarakan untuk menjamin kepastian hukum, untuk memenuhi kebutuhan masyarakat dan pemerintah. ${ }^{7}$

Pelaksanaan pendaftaran tanah meliputi kegiatan pendaftaran tanah untuk pertama kali (initial registration) dan pemeliharaan pendaftaran tanah (maintenance). ${ }^{8}$

Penting kiranya bagi masyarakat untuk terus aktif memelihara data pendaftaran tanahnya. Hal ini karena sangat besar kemungkinan terjadinya kasus pertanahan, berupa konflik dan sengketa yang timbul mengenai

\footnotetext{
${ }^{5}$ Harsono, Boedi. (2008). Hukum Agraria Indonesia: Sejarah Pembentukan Undang-Undang Pokok Agraria, Isi dan Pelaksanaannya. Jakarta: Djambatan, p. 163.

${ }^{6}$ Zarqoni, Mohammad Machfudh. (2015). Hak Atas Tanah. Jakarta: PT. Prestasi Pustakaraya, p. 47.

${ }^{7}$ Sutedi, Adrian. (2014). Peralihan Hak Atas Tanah. Jakarta: Sinar Grafika, p. 114.

${ }^{8}$ Sumarja, FX. (2010). Hukum Pendaftaran Tanah. Bandar Lampung: Universitas Lampung, p. 20.
} 
pemilikan, penguasaan, penggunaan dan pemanfaatan tanah. Konflik dan sengketa tersebut banyak terkait dengan perbuatan hukum, misalnya jual beli, tukar menukar, hibah, lelang, wakaf, dan sebagainya, maupun peristiwa hukum, misalnya pewarisan tanah.

Pendaftaran peralihan hak atas tanah berdasarkan lelang karena hak mendahulu negara tidak diatur secara lugas di dalam PP 24 Tahun 1997 tentang Pendaftaran Tanah. Lelang karena utang pajak dalam peraturan ini termasuk dalam kategori lelang eksekutorial, dan disinggung dalam penjelasan Pasal 41 ayat (4) yang isinya ialah sebagai berikut:

"Lelang eksekusi meliputi lelang dalam rangka putusan Pengadilan, hak tanggungan, sita pajak, sita Kejaksaan/Penyidik dan sita Panitia Urusan Negara. Dalam pelelangan eksekusi kadang-kadang tereksekusi menolak untuk menyerahkan sertipikat asli hak yang akan dilelang. Hal ini tidak boleh mengahalangi dilaksanakannnya lelang. Oleh karena itu lelang eksekusi tetap dapat dilaksanakan walaupun sertipikat asli tanah tersebut tidak dapat diperoleh Pejabat lelang dari tereksekusi." Berdasarkan isi dari penjelasan pasal di atas, maka lelang berdasarkan hak mendahulu negara ialah lelang eksekutorial.

Di Kota Bandar Lampung, umumnya pendaftaran tanah karena lelang hak atas tanah terjadi karena kredit macet hak tanggungan, sedangkan lelang berdasarkan hak mendahulu negara jarang sekali terjadi. Hal ini juga masih belum adanya peraturan lebih lanjut terkait lelang tersebut di lingkungan Badan Pertanahan Nasional/Kementerian Agraria dan Tata Ruang.

Berkaitan dengan hal tersebut, meskipun lelang berdasarkan hak mendahulu negara jarang ada, namun ternyata di Kantor Pertanahan Kota Bandar Lampung peralihan hak karena lelang ini pernah terjadi.

Tanah tersebut berjenis hak milik dan merupakan harta pribadi atas nama perorangan, yakni Tuan A, dimana tanah itu sedang dalam keadaan sengketa waris, dan sempat dmintakan pencatatan pemblokiran selama 30 (tiga puluh) hari di kantor Pertanahan Kota Bandar Lampung oleh salah satu pihak yang bersengketa untuk persiapan pengajuan blokir dengan sita jaminan.

Pada saat bersamaan, tanah tersebut dilelang oleh Kantor Pelayanan Kekayaan Negara dan Lelang (KPKNL) berdasarkan permintaan Kantor Pelayanan Pajak (KPP) Pratama Tanjung Karang Bandar Lampung, untuk pelunasan tunggakan Pajak Penghasilan $(\mathrm{PPh})$ dan Pajak Pertambahan Nilai (PPN) dari Perseroan Terbatas (selanjutnya akan disebut sebagai PT. XYZ) milik Tuan A.

Tanah yang dipersengketakan itu dilelang setelah masa 30 (tiga puluh) hari pencatatan di buku tanah selesai, dan kini telah beralih ke pihak ketiga (pembeli lelang). Pihak yang memohon blokir merasa haknya dirugikan karena terjadinya peralihan hak tersebut, dan mempertanyakan keabsahan 
peralihan hak karena lelang berdasarkan hak mendahulu negara terhadap tanah yang bersangkutan, karena tanah itu tercatat atas nama perseorangan, dan bukan atas nama PT. Terlebih lagi tanah itu sedang dalam sengketa dan sudah dilakukan pencatatan blokir di Kantor Pertanahan kota Bandar Lampung.

Berdasarkan latar belakang di atas, maka Peneliti tertarik untuk melakukan penelitian dalam bentuk tesis dengan judul "Status Hukum Peralihan Hak Atas Tanah Yang Diperoleh Dari Lelang Berdasarkan Hak Mendahulu Negara."

Berdasarkan uraian latar belakang di atas, maka yang menjadi permasalahan dalam penelitian ini yang pertama adalah bagaimanakah status hukum peralihan hak atas tanah yang diperoleh dari lelang berdasarkan hak mendahulu negara terhadap tanah yang sedang dalam sengketa?; kedua, bagaimanakah perlindungan hukum bagi pihak-pihak yang terkait dalam pelaksanaan pendaftaran peralihan hak atas tanah karena lelang berdasarkan hak mendahulu negara terhadap tanah yang sedang dalam sengketa?

Jenis penelitian yang digunakan di dalam penelitian ini adalah penelitian hukum normatif diikuti dengan pendekatan secara empiris. Tipe penelitian ini adalah eksploratori. Sumber data yang digunakan dalam penelitian ini berupa: data primer, data sekunder, dan data tersier. Prosedur pengumpulan data dilakukan dengan studi pustaka, studi dokumen dan wawancara. Pengolahan data dilakukan dengan menggunakan seleksi data, klasifikasi data, dan penyusunan data. Analisis data menggunakan analisis kualitatif.

\section{B. Pembahasan}

\section{Status Hukum Peralihan Hak Atas Tanah Yang Diperoleh Dari Lelang Berdasarkan Hak Mendahulu Negara Terhadap Tanah Yang Sedang Dalam Sengketa}

Negara Indonesia adalah negara hukum, oleh karenanya, segala sesuatu yang menyangkut kehidupan bernegara harus diatur dengan hukum. Begitu pun halnya dengan permasalahan peralihan hak atas tanah.

Peralihan hak atas tanah yang dilaksanakan di Kantor Pertanahan merupakan salah satu bentuk dari kegiatan pemeliharaan data pendaftaran tanah, dan terjadi karena adanya peristiwa hukum yang menyebabkan terjadinya perubahan data, baik data yuridis maupun data fisik. Peralihan yang terjadi karena perubahan data yuridis misalnya karena jual-beli, tukarmenukar, hibah, inbreng, waris, lelang, dan sebagainya. 
Umumnya peralihan hak atas tanah karena lelang yang didaftarkan di Kantor Pertanahan Kota Bandar Lampung adalah lelang yang terjadi karena kredit macet hak tanggungan. ${ }^{9}$

Meskipun peralihan hak karena lelang yang dilaksanakan di Kantor Pertanahan Kota Bandar Lampung karena masalah tunggakan pembayaran hak tanggungan, tidak berarti bahwa masalah utang-piutang adalah satusatunya penyebab mutlak dilaksanakannya lelang hak atas tanah.

Lelang bisa saja terjadi karena sebab-sebab yang lain di luar permasalahan utang-piutang. Hal ini dapat dilihat dalam PMK No. 27/PMK.06/2016, yang membagi lelang dalam tiga jenis, yaitu: ${ }^{10}$

a. Lelang Eksekusi;

b. Lelang Noneksekusi Wajib; dan

c. Lelang Noneksekusi Sukarela.

Lelang Eksekusi meliputi lelang dalam rangka pelaksanaan putusan pengadilan, hak tanggungan, sita pajak, sita Kejaksaan/Penyidik dan sita Panitia Urusan Piutang Negara. ${ }^{11}$ Jadi, selain hak tanggungan, adapula lelang yang dilaksanakan karena sebab-sebab lainnya, salah satunya ialah Lelang Eksekusi Pajak.

Peralihan hak karena Lelang Eksekusi Pajak di Kantor Pertanahan Kota Bandar Lampung terjadi pada sebidang tanah pertanian bersertipikat jenis hak milik an. Tuan A, untuk pembayaran utang pajak PT. XYZ.

PT. XYZ adalah badan usaha berbentuk Perseroan Terbatas (PT), dimana yang dimaksud dengan PT ialah badan hukum yang merupakan persekutuan modal, didirikan berdasarkan perjanjian, melakukan kegiatan dengan modal dasar yang seluruhnya terbagi dalam saham dan memenuhi persyaratan yang ditetapkan dalam Undang-Undang PT dan peraturan pelaksana lainnya. ${ }^{12}$

Sebagai subjek hukum, PT XYZ adalah wajib pajak, sehingga ia mempunyai hak dan kewajiban perpajakan. ${ }^{13}$ Bentuk pemenuhan kewajiban perpajakan ialah membayar pajak, salah satunya berupa pembayaran $\mathrm{PPh}$ Pasal 25 dan PPN. Untuk memenuhi hak dan kewajiban PT di bidang perpajakan, maka dibutuhkan orang-perorangan yang bertindak sebagai wakil PT atas nama PT. Berdasarkan Pasal 32 ayat (1) No. 28 Tahun 2007 tentang Perubahan Ketiga atas Undang-Undang No. 6 Tahun 1983 tentang Ketentuan Umum dan Tata Cara Perpajakan, yang selanjutnya akan disebut UU KUP, orang yang dimaksud adalah pengurus badan/PT.

\footnotetext{
${ }^{9}$ Wawancara dengan Sutrisno, Pegawai Loket Balik Nama Kantor Pertanahan Kota Bandar Lampung, Tanggal 21 Juli 2016 Pukul 14.00 WIB.

${ }^{10}$ Pasal 5 PMK Nomor 27/PMK.06/2016. Tentang Petunjuk Pelaksanaan Lelang.

${ }^{11}$ Lihat Pasal 40 ayat (4) PMNA/KBPN RI No. 3 Tahun 1997.

${ }^{12}$ Pasal 1 ayat (1) UU PT

${ }^{13}$ Lihat Pasal 2 UU KUP.
} 
Pengurus PT dalam UU No. 40 tahun 2007 Tentang Perseroan Terbatas (UU PT) disebut organ PT. Organ Perseroan sebagaimana diatur dalam Undang-Undang Perseroan Terbatas terdiri dari :

\section{a. Rapat Umum Pemegang Saham (RUPS)}

Rapat Umum Pemegang Saham (RUPS) adalah Organ Perseroan yang mempunyai wewenang yang tidak diberikan kepada Direksi atau Dewan Komisaris dalam batas yang ditentukan dalam Undang-Undang PT dan/atau anggaran dasar. Pemegang saham perseroan tidak bertanggung jawab secara pribadi atas perikatan yang dibuat atas nama Perseroan dan tidak bertanggung jawab atas kerugian Perseroan melebihi saham yang dimiliki. ${ }^{14}$

Menurut I. G. Widjaja, sejak sebuah PT berstatus sebagai badan hukum, maka sejak saat itu hukum memperlakukan Pemegang Saham dan Pengurus (Direksi) terpisah dari PT itu sendiri yang dikenal dengan istilah separate legal personality, yaitu sebagai individu yang berdiri sendiri. Dengan demikian pemegang saham yang mempunyai kepentingan dalam kekayaan PT, juga tidak bertanggung jawab atas utang-utang perusahaan atau PT. ${ }^{15}$

Pembatasan tanggung jawab pemegang saham diatur dalam Pasal 3 ayat (1) UU PT, yang menyatakan bahwa, "Pemegang saham perseroan tidak bertanggung jawab secara pribadi atas perikatan yang dibuat atas nama perseroan melebihi saham yang dimiliki."

Menyikapi isi Pasal 3 ayat (1) UU PT tersebut, Yahya Harahap memberikan pendapat tentang apa yang dimaksud dengan "pertanggung jawaban terbatas", yaitu: ${ }^{16}$

a. Perseroan Terbatas tidak bertanggung jawab terhadap utang pemegang saham (not liable of its shareholders), sebaliknya pemegang saham tidak bertanggung jawab terhadap utang perseroan;

b. Kerugian yang ditanggung pemegang saham hanya terbatas harga saham yang mereka investasikan (their lose is limited to their investment);

Pemegang saham, tidak bertanggung jawab lebih lanjut kepada kreditur perseroan atas harta pribadinya.

\section{b. Direksi}

Direksi adalah Organ Perseroan yang berwenang dan bertanggung jawab penuh atas pengurusan Perseroan untuk kepentingan Perseroan, sesuai

\footnotetext{
${ }^{14}$ Pasal 3 ayat (1) UU No. 40 tahun 2007.

${ }^{15}$ Kurniawan. (2014). Hukum Perusahaan Karakteristik Badan Usaha Berbadan Hukum dan Tidak Berbadan Hukum di Indonesia. Yogyakarta: Genta Publishing, p. 64.

${ }^{16}$ Harahap, M. Yahya. (2009). Hukum Perseroan Terbatas. Jakarta: Sinar Grafika, p. 59.
} 
dengan maksud dan tujuan Perseroan serta mewakili Perseroan, baik di dalam maupun di luar pengadilan sesuai dengan ketentuan anggaran dasar.

\section{c. Dewan Komisaris}

Dewan Komisaris adalah Organ Perseroan yang bertugas melakukan pengawasan secara umum dan/atau khusus sesuai dengan anggaran dasar serta memberi nasihat kepada Direksi.

Kewajiban pembayaran pajak belum dipenuhi oleh perusahaan karena satu dan lain hal pada saat perusahaan masih aktif. Ketika perusahaan tersebut pailit, utang pajaknya masih juga belum dibayarkan.

Negara yang dalam hal ini diwakili oleh Kantor Pelayanan Pajak (KPP) Pratama Tanjung Karang segera mengambil tindakan pengamanan harta-harta dari PT. XYZ agar tidak jatuh ke tangan kreditur-kreditur lain sebelum utang kepada negara dilunasi. Setelah aset-aset PT. XYZ dipergunakan seluruhnya untuk membayar utang pajak pada negara dan ternyata jumlahnya belum menutup seluruh utang pajaknya, maka KPP Pratama melaksanakan lelang pada sejumlah harta milik Tuan A selaku pemilik PT. XYZ, salah satunya adalah lelang terhadap sertipikat tanah milik pribadi Tuan A. Pendaftaran peralihan hak atas tanah di Kantor Pertanahan Kota Bandar lampung kemudian segera dilaksanakan oleh pihak ketiga (pembeli lelang) setelah lelang selesai dilaksanakan.

Terjadinya peralihan hak atas tanah ke tangan pihak ketiga selaku pembeli lelang kemudian menimbulkan keberatan dari salah satu pihak yang bersengketa, yang menilai peralihan itu tidak sah. Keberatan-keberatan yang diajukan salah satu pihak ahli waris adalah:

a. Tanah yang dilelang adalah harta perorangan dan bukan harta PT. Pada saat dilaksanakan lelang, tanah itu bersih dari utang-piutang dengan pihak manapun.

b. Tanah yang dilelang adalah tanah yang sedang dalam sengketa waris, yang sudah dimintakan blokir di Kantor Pertanahan kota Badar Lampung. Peralihan hak atas tanah karena lelang itu terkesan sewenang-wenang dan melanggar hak waris dari para ahli waris Tuan A yang berhak atas tanah.

Untuk dapat menentukan sah atau tidaknya peralihan hak atas tanah tersebut, maka akan ditelaah terlebih dahulu dasar hukum negara dapat melaksanakan lelang terhadap tanah milik perorangan untuk melunasi utang dari PT.

Istilah perseroan terbatas terdiri dari dua kata, yaitu Perseroan dan Terbatas. Perseroan merujuk pada modal PT yang terdiri atas sero-sero atau saham-saham. Adapun kata terbatas merujuk pada tanggung jawab 
pemegang saham yan luasnya hanya terbatas pada nilai nominal semua saham yang dimilikinya. ${ }^{17}$

Suatu Perseroan Terbatas sebagai perusahaan bisnis sedikitnya memiliki lima karakteristik struktural, yaitu: ${ }^{18}$

a. Legal Personality (badan hukum);

b. Limited Liability (tanggung jawab terbatas);

c. Transferable Shares (saham dapat dialihkan);

d. Centralized Management (manajemen terpusat);

e. Shared Ownership (saham dapat dialihkan).

Persoalan pertanggungjawaban terbatas tersebut tidaklah mutlak. Dalam keadaan tertentu tanggung jawab terbatas tersebut tidak berlaku karena ada pengecualiannya. Di sini terlihat bahwa UUPT menganut piercing corporate veil atau menyingkap tabir atau cadar perseroan. Secara sederhana dapat dikatakan bahwa tanggung jawab Pemegang Saham dan juga pengurus (Direksi dan Komisaris) dapat menjadi tidak terbatas, dalam hal-hal tertentu. ${ }^{19}$

Kata piercing berarti mengoyak atau menembus, sementara kata veil berarti kerudung atau cadar, maka pengertian piercing the corporate veil secara harfiah adalah cadar badan hukum dikoyak atau ditembus. Doktrin ini mengajarkan bahwa ada kemungkinan membebankan tanggung jawab atas pihak lain yang bukan perusahaan itu sendiri, sungguhpun perbuatan tersebut dilakukan secara sah oleh dan atas nama perusahaan sebagai badan hukum. ${ }^{20}$

Doktrin Piercing The Corporate Veil Piercing The Corporate Veil bertujuan untuk menghindari hal-hal yang tidak adil, terutama bagi phak luar perseroan dari tindakan sewenang-wenang atau tidak layak yang dilakukan atas nama perseroan, baik yang terbit dari suatu transaksi dengan pihak ketiga ataupun yang timbul dari perbuatan menyesatkan atau perbuatan melawan hukum. Pada dasarnya doktrin ini akan diterapkan jika terdapat keadaan bahwa sangat tidak adil jika dalam hal yang demikian, tanggung jawab hanya dimintakan pada perusahaan sebagai badan hukum semata. ${ }^{21}$

Keberadaan doktrin Piercing the Corporate Veil dalam UU PT dapat dilihat dalam beberapa pasal dari UU PT, yaitu:

\footnotetext{
${ }^{17}$ Khairandy, Ridwan. (2007). "Perseroan Terbatas Sebagai Badan Hukum”, Jurnal Hukum Bisnis, 26: 5.

${ }^{18}$ Hansmann, Henry dan Kraakman, Reiner. (2014). “What is: Corporate Law?” Dalam Kurniawan. Op.Cit., p. 58.

${ }^{19}$ Ais, Chatamarrasjid. (2004). Penerobosan Cadar Perseroan dan Soal-Soal Aktual Hukum Perusahaan. Bandung: PT. Citra Aditya Bakti, p. 8.

${ }^{20}$ Gifis, Steven H. dalam Fuady, Munir. (1996). Hukum Bisnis Dalam Teori dan Praktek, Buku Ketiga. Bandung:PT. Citra Aditya Bakti, p. 97.

${ }^{21}$ Kurniawan. Op.Cit., p. 81.
} 


\section{a. Pemegang Saham}

Doktrin ini diatur dalam Pasal 3 ayat (2) yang merupakan perkecualian dari Pasal 3 ayat (1) UU PT yang menyatakan bahwa Pemegang saham perseroan tidak bertanggung jawab secara pribadi atas perikatan yang dibuat atas nama Perseroan dan tidak bertanggung jawab atas kerugian perseroan melebihi saham yang dimiliki. Perkecualian tanggung jawab Pemegang saham pada ayat (1) tidak berlaku apabila:

1) persyaratan perseroan sebagai badan hukum belum atau tidak terpenuhi;

2) pemegang saham yang bersangkutan baik langsung maupun tidak langsung dengan itikad buruk memanfaatkan perseroan untuk kepentingan pribadi;

3) pemegang saham yang bersangkutan terlibat dalam perbuatan melawan hukum yang dilakukan oleh perseroan; atau

4) pemegang saham yang bersangkutan baik langsung maupun tidak langsung secara melawan hukum menggunakan kekayaan perseroan, yang mengakibatkan kekayaan perseroan menjadi tidak cukup untuk melunasi utang perseroan.

Ketentuan Pasal 3 ayat (2) UU PT tidak ada satu ketentuan pun yang menyatakan pihak mana yang sebenarnya dilindungi dengan diberlakukannya prinsip piercing the corporate veil. Namun demikian dengan melihat pada ketentuan yang dinyatakan dalam Pasal 3 ayat (2) UU PT dapat diketahui bawa perlindungan diberikan pada kreditor PT. ${ }^{22}$

\section{b. Direksi}

Dalam melaksanakan tugasnya, Direksi harus melaksanakannya dengan itikad baik dan penuh tanggung jawab, sebagaimana diatur dalam Pasal 97 ayat (2) UU PT. Tidak ada rumusan yang jelas mengenai unsur "itikad baik" dan "penuh tanggung jawab". Sutan Remy Sjahdeini menyatakan bahwa kedua unsur tersebut dapat dikaitkan dalam standar of care atau standar kehati-hatian, yaitu: ${ }^{23}$

1) Anggota Direksi tidak boeh melakukan kegiatan-kegiatan atas beban biaya perseroan, apabila tidak memberikan sangat kecil manfaat pribadi yang diperoleh oleh anggota Direksi yang bersangkutan.

2) Anggota Direksi tdak boleh menjadi pesaing bagi perseroan yang dipimpinnya.

3) Anggota Direksi harus menolak untuk mengambil keputusan mengenai sesuatu hal yang diketahuinya atau sepatutnya diketahui akan dapat

${ }^{22}$ Kurniawan. (2014). "Tanggung Jawab Pemegang Saham Perseroan Terbatas Menurut Hukum Positif", Jurnal Hukum Mimbar Hukum. 26(1): 80-81.

${ }^{23}$ Sjahdeini, Sutan Remy. (2001). "Tanggung Jawab Pribadi Direks dan Komisaris", Jurnal Hukum Bisnis. 14: 100. 
mengakibatkan perseroan melanggar ketentuan perundang-undangan yang berlaku sehingga perseroan terancam dikenai sanksi oleh otoritas yang berwenang.

4) Anggota Direksi dengan sengaja atau karena kelalaian nya telah tidak melakukan atau telah tidak cukup melakukan upaya atau tindakan yang perlu diambil untuk mencegah timbulnya kerugian bagi perseroan.

5) Anggota Direksi dengan sengaja atau karena kelalaiannya telah tidak melakukan atau telah tidak cukup melakukan upaya atau tindakan yang perlu diambil untuk meningkatkan keuntungan perseroan.

Jika Anggota Direksi melaksanakan tugasnya tidak memenuhi unsur itikad baik dan tanggung jawab, maka ia dapat dimintakan pertanggung jawaban baik secara pribadi sebagaimana diatur dalam Pasal 97 ayat (3) maupun secara renteng antar Anggota Direksi sebagaimana diatur dalam Pasal 97 ayat (4) UU PT.

Pertanggungjawaban pribadi Direksi juga diatur dalam Pasal 104 ayat (2) UUPT, yang menyatakan bahwa, "Dalam hal kepailitan terjadi karena kesalahan atau kelalaian direksi dan harta pailit tidak cukup untuk membayar seluruh kewajiban perseroan dalam kepailitan tersebut, setiap anggota Direksi secara tanggung renteng bertanggung jawab atas seluruh kewajiban yang tidak terlunasi dari harta pailit tersebut."

Penagihan pembayaran utang pajak PT kepada Direksi diatur Pasal 32 ayat (2) UU KUP dan penjelasannya, bahwa pengurus badan sebagaimana dimaksud pada ayat (1) bertanggung jawab secara pribadi dan/atau renteng atas pembayaran pajak yang terutang, kecuali apabila dapat membuktikan dan meyakinkan Direktur Jenderal bahwa mereka dalam kedudukannya benar-benar tidak mungkin dibebani tanggung jawab atas pajak yang terutang tersebut.

\section{c. Komisaris}

Komisaris dapat dimintakan pertanggung jawaban baik secara pribadi (Pasal 114 ayat (3)) maupun secara tanggung renteng (Pasal 114 ayat (4)) UU PT, jika dalam melaksanakan tugas pengawasan dan pemberian nasehat kepada Direksi tidak dilaksanakan dengan itikad baik, kehati-hatian, dan bertanggung jawab.

Berdasarkan ketentuan di atas, maka pengenaan lelang terhadap tanah pribadi untuk pelunasan utang pajak PT adalah sah, karena telah sesuai dan tidak bertentangan dengan hukum yang berlaku. Meskipun dalam UU PT dinyatakan bahwa harta pribadi organ PT terpisah dengan harta perseroan, namun Undang-undang ini masih membuka kemungkinan untuk menagih pembayaran kepada organ PT sepanjang dalam melaksanakan tugasnya dilaksanakan tidak dengan itikad baik maupun tanggung jawab. 
Prinsip pertanggungjawaban terbatas pemegang saham perseroan tidak terancam dan tetap kokoh sekalipun ada doktrin penerobosan atau penyingkapan tabir perseroan. Doktrin ini akan dipakai karena perseroan hanyalah suatu topeng atau menyembunyikan maksud sesungguhnya. ${ }^{24} \mathrm{Jadi}$, hukum akan melindungi Pemegang Saham, Direksi, maupun Komisaris yang mempunyai itikad baik.

Mengenai unsur kesalahan dan kelalaian, terkait dengan pelunasan utang pajak memang belum diberikan batasan yang jelas dalam UU PT. Artinya, harus ada pembuktian terlebih dahulu bahwa ada unsur kesengajaan atau kelalaian dari Direksi atas penunggakan utang pajak PT. XYZ, yang menyebabkan lelang dapat dilaksanakan.

Pada dasarnya pembayaran pajak adalah kewajiban yang lahir dari undang-undang bagi setiap subjek pajak, baik itu perorangan maupun badan hukum, yang besaran dan cara penghitungannya telah diatur dalam undangundang pajak. Penunggakan pembayaran pajak PPh maupun PPN oleh PT. XYZ adalah bentuk kesalahan dan kelalaian dari pengurus PT, sehingga KPP Pratama mempunyai dasar yang kuat untuk melelang aset pribadi Tuan A untuk pelunasan utang pajak PT. XYZ.

Implikasi dari sahnya penuntutan utang pajak PT. XYZ menggunakan tanah pribadi Tuan A menyebabkan tanah tersebut dapat dilelang oleh KPKNL dan dapat didaftarkan peralihan haknya di Kantor Pertanahan.

Sampai sejauh ini, bisa dikatakan bahwa peralihan hak atas tanah tersebut adalah sah sebab telah memenuhi syarat-syarat formal lelang diantaranya Surat Keterangan Pendaftaran Tanah (SKPT) dari Kantor Pertanahan, kecuali bisa dibuktikan sebaliknya oleh mereka yang berkepentingan.

\section{Perlindungan Hukum Bagi Pihak-Pihak Yang Terkait Dalam Pelaksanaan Pendaftaran Hak Atas Tanah Karena Lelang Berdasarkan Hak Mendahulu Negara Terhadap Tanah Yang Sedang Dalam Sengketa}

Dalam pendaftaran tanah, baik pertama kali maupun pemeliharaan data pendaftaran tanah, sangat dimungkinkan terjadi sengketa dan konflik kepentingan antara pihak-pihak yang terkait. Begitu pula halnya dengan peralihan hak karena lelang berdasarkan Hak Mendahulu Negara terhadap bekas tanah atas nama Tuan A yang kini telah beralih ke tangan pihak ketiga (pembeli lelang). Peralihan hak ini menimbulkan rasa ketidakpuasan dari para ahli waris. hal ini dapat dimaklumi, karena setiap orang berhak untuk mempertahankan haknya.

${ }^{24}$ Chatamarrasjid. Op.Cit., p. 16. 
Menurut Pasal 834 KUHPerdata, seorang ahli waris berhak untuk menuntut supaya segala apa saja yang termasuk harta peninggalan si meninggal diserahkan padanya berdasarkan haknya sebagai ahli waris. Hak penuntutan ini menyerupai hak penuntutan seorang pemilik suatu benda, dan menurut maksudnya penuntutan itu harus ditujukan pada orang yang menguasai satu benda warisan dengan maksud untuk memilikinya. ${ }^{25}$

Di lain pihak, Kantor Pertanahan Kota Bandar Lampung, KPP Pratama Tanjung Karang, dan KPKNL selaku instansi yang terkait dengan proses lelang hingga beralihnya hak atas tanah, akan mempertahankan tindakan administrasi yang dilakukannya. Begitu pun dengan pembeli lelang yang akan mempertahankan hak yang telah ia peroleh sebagai pemilik tanah yang sah.

Peralihan hak atas tanah yang diperoleh dari lelang berdasarkan hak mendahulu negara yang dilakukan oleh KPP Pratama Tanjung Karang, KPKNL Bandar Lampung, dan Kantor Pertanahan Bandar Lampung adalah sah sebab terpenuhinya unsur kesengajaan dan kelalaian Direksi sebagaimana diatur dalam Pasal 32 ayat (2) UU KUP dan Pasal 97 ayat (3) dan (4) UU PT, maka perlindungan hukum bagi ketiga instansi tersebut adalah dibebaskan dari segala tuntutan.

Terhadap KPP Pratama Tanjung Karang, perlindungan hukum diberikan karena KPP melaksanakan tugas negara berdasarkan hak mendahulu negara. Hak ini menjadi dasar bagi KPP Pratama Tanjung Karang untuk menagih utang pajak dari PT. XYZ melalui prosedur dan caracara yang diatur oleh hukum.

Pada dasarnya, hak mendahulu negara ialah hak tagih Negara atas utang pajak dari Wajib Pajak/Penanggung Pajak. Pengenaan hak mendahulu ini berlaku untuk semua jenis pajak, baik itu Pajak Pusat maupun Pajak Daerah. ${ }^{26}$

Hak Mendahulu Negara diatur dalam pasal 21 ayat (1) UU KUP yang menyatakan bahwa negara mempunyai hak mendahulu atas barang-barang milik penganggung pajak dan hak mendahulu lainnya.

Hak Mendahulu Negara diatur dalam pasal 21 ayat (1) UU KUP yang menyatakan bahwa negara mempunyai hak mendahulu atas barang-barang milik penganggung pajak dan hak mendahulu lainnya.

Lebih lanjut dalam Pasal 21 ayat (3a) diatur bahwa dalam hal wajib pajak dinyatakan pailit, bubar, atau dilikuidasi, maka kurator, likuidator, atau orang, atau badan yang ditugasi untuk melakukan pemberesan dilarang membagikan harta Wajib Pajak dalam pailit, pembubaran, atau likuidasi

\footnotetext{
${ }^{25}$ Subekti. (2001). Pokok-Pokok Hukum Perdata. Jakarta: PT. Intermasa, p. 96.

${ }^{26}$ Wawancara dengan Prayoga, Pegawai KPP Pratama Tanjung Karang, Tanggal 16 Agustus 2016 Pukul 14.15 WIB.
} 
kepada pemegang saham atau kreditur lainnya sebelum menggunakan harta tersebut untuk membayar utang pajak Wajib Pajak tersebut.

Jika dilihat dari rumusan pasal tersebut, maka Negara mempunyai hak yang diistimewakan dan hak yang didahulukan dalam pelunasan utang-utang pajak di atas kreditur-kreditur lainnya.

KPP Pratama Tanjung Karang selaku fiskus pajak mempunyai hak untuk menerbitkan surat paksa dan surat perintah melaksanakan penyitaan. Dalam hal wajib pajak tidak melunasi utang pajak sebagaimana ditentukan dalam Surat Ketetapan Pajak Kurang Bayar setelah jatuh tempo pembayaran, maka fiskus mempunyai hak untuk menerbitkan Surat Paksa agar Wajib Pajak dalam waktu yang ditentukan yaitu 2x24 jam harus melunasi utang pajaknya. Apabila dalam jangka waktu tersebut Wajib Pajak tetap tidak melunasinya, maka fiskus dapat menindaklanjutinya dengan menerbitkan Surat Perintah melaksanakan penyitaan, agar terhadap harta kekayaan Wajib Pajak dilakukan penyitaan guna sebagai jaminan untuk melunasi utang pajaknya. ${ }^{27}$

UU No. 19 Tahun 2000 Tentang Perubahan Atas Undang-Undang No. 19 Tahun 1997 Tentang Penagihan Pajak Dengan Surat Paksa (UU PPSP) memberikan kedudukan yang sangat kuat terhadap surat paksa. Hal ini dapat dilihat dalam pasal 7 ayat (1) UU PPSP yang berisi:

"Surat Paksa berkepala kata-kata "DEMI KEADILAN BERDASARKAN KETUHANAN YANG MAHA ESA", mempunyai kekuatan eksekutorial dan kedudukan hukum yang sama dengan putusan pengadilan yang telah mempunyai kekuatan hukum tetap."

Kedudukan surat paksa diperjelas lagi di penjelasan Pasal 7 ayat (1) UU PPSP yang menyatakan bahwa tujuan Surat Paksa diberikan kekuatan eksekutorial yang sama dengan putusan pengadilan adalah agar tercapai efektivitas dan efisiensi penagihan pajak yang didasari Surat Paksa, ketentuan ini memberikan kekuatan eksekutorial serta memberi kedudukan hukum yang sama dengan grosse akte yaitu putusan pengadilan perdata yang telah mempunyai kekuatan hukum tetap. Dengan demikian, Surat Paksa langsung dapat dilaksanakan tanpa bantuan putusan pengadilan lagi dan tidak dapat diajukan banding.

Pelaksanaan lelang sertipikat hak atas tanah berdasarkan hak mendahulu negara karena penunggakan utang pajak dilaksanakan setelah dilakukannya penagihan utang pajak oleh KPP Pratama. Penagihan tersebut berupa penerbitan Surat Teguran, Penagihan Seketika dan Sekaligus, Surat Paksa, Penyitaan, dan lelang.

${ }^{27}$ Ilyas, Wirawan B. dan Burton, Richard. (2007). Hukum Pajak Edisi 3. Jakarta: Salemba Empat, p. 160-161. 
Melaksanakan lelang adalah kewajiban bagi Kepala KPKNL ataupun Pejabat Lelang Kelas II, sepanjang permohonan lelang yang diajukan kepadanya sudah lengkap dan telah memenuhi Legalitas Formal Subyek dan Obyek Lelang. ${ }^{28}$

Di Kantor Pertanahan Kota Bandar Lampung, masalah kewarisan rentan menimbulkan sengketa, baik antar ahli waris itu sendiri, ahli waris dengan pihak ketiga yang mempunyai kepentingan terhadap tanah waris, maupun antara ahli waris dengan badan hukum. ${ }^{29}$

Sengketa tanah dapat berupa sengketa administratif, sengketa perdata, sengketa pidana terkait dengan pemilikan, transaksi, pendaftaran, penjaminan, pemanfaatan, penguasaan, dan sengketa hak ulayat. Suatu sengketa tentu subjeknya tidak hanya satu, namun lebih dari satu, entah itu antar individu, kelompok, organisasi, bahkan lembaga besar sekalipun seperti Badan Usaha Milik Negara (BUMN) ataupun negara. ${ }^{30}$

Sengketa waris adalah merupakan sengketa perdata, mengenai siapa yang lebih berhak atas suatu bidang tanah. Biasanya, jika terjadi sengketa waris, salah satu pihak akan mengajukan pencatatan blokir sertipikat di Kantor Pertanahan Kota Bandar Lampung.

Mengenai blokir sertipikat sendiri sering menimbulkan kesalahpahaman di tengah masyarakat. Kesalahpahaman tersebut antara lain: ${ }^{31}$

a. Blokir tidak berbatas waktu. Setelah suatu obyek hak atas tanah diblokir, maka tanahnya akan terus status quo sampai ia sendiri yang mencabut blokirnya;

b. Blokir Berlaku selama 30 (tiga puluh) hari dan setelahnya dapat diperpanjang lagi secara terus-menerus setelah masa 30 (tiga puluh) hari selesai.

Menyikapi kesalahpahaman masyarakat mengenai blokir, Bapak Badarudin Umar selaku Kepala Seksi Hak Tanah dan Pendaftaran Tanah Kantor Pertanahan Kota Bandar Lampung menerangkan mengenai blokir sebagaimana dimaksud dalam Pasal 126 ayat (2) PMNA/KBPN No. 3 Tahun 1997 bahwa, "Sebenarnya blokir yang dimaksud oleh Pasal 126 ayat (2) bukanlah pencatatan selama 30 (tiga puluh) hari, melainkan blokir yang yang terjadi karena perintah status quo dari hakim diikuti adanya putusan sita jaminan. Jadi, waktu 30 (tiga puluh) hari yang dimaksudkan ialah waktu yang disediakan oleh Kantor Pertanahan kepada Pemohon untuk mempersiapkan pengajuan sita jaminan di pengadilan. Apabila setelah waktu

\footnotetext{
${ }^{28}$ Lihat Pasal 13 PMK. 27/PMK.06/2016.

29 Wawancara dengan Badarudin Umar, Kepala Seksi Hak Tanah dan Pendaftaran Tanah Kantor Pertanahan Kota Bandar Lampung, 18 Agustus 2016, Pukul 13.10 WIB.

${ }^{30}$ Limbong, Bernhard. (2014). Politik Pertanahan. Jakarta: Margaretha Pustaka, p. 65.

${ }^{31}$ Wawancara dengan Luthfi Muchtaedy, Petugas Loket Pendaftaran Hak Atsa Tanah Kantor Pertanahan Kota Bandar Lampung, Tanggal 16 Agustus 2016 pukul 14.10 WIB.
} 
30 (tiga puluh) hari yang diberikan oleh Kantor Pertanahan, Pemohon blokir tidak melakukan tindak lanjut berupa pengajuan sita jaminan di pengadilan, maka blokir tersebut akan gugur dengan sendirinya. ${ }^{32}$

Sita jaminan (Conservatoir Beslag) adalah suatu tindakan hukum yang diambil Pengadilan mendahului putusan. Artinya, sita telah dilakukan atas harta Tergugat sebelum diperiksa pokok perkara atau dapat dilakukan pada saat proses perkara sedadng berjalan, sebelum Pengadilan menjatuhkan putusan. Peranan upaya sita jaminan di dalam praktek beracara di muka Pengadilan amatlah penting dan memegang peranan yang tidak kecil pula. Dengan dilakukannya tindakan penyitaan atas barang/harta kekayaan Tergugat tersebut, maka sementara ia kehilangan wewenang untuk menguasai dan barang-barang tersebut disimpan (diconserveer) untuk jaminan serta tidak boleh dialihkan, digelapkan atau dipindahtangankan kepada orang lain. ${ }^{33}$

Sita jaminan dimaksudkan guna menjamin kepentingan Penggugat atau terjamin haknya sekiranya gugatan dikabulkan nanti dan undangundang menyediakan upaya untuk menjamin hak tersebut, yaitu dengan penyitaan (arrest, beslag). ${ }^{34}$

Setelah blokir gugur, maka keadaan sertipikat kembali sebagaimana keadaan semula sebelum terjadinya blokir. Artinya, pada sertipikat yang bersangkutan dapat dilaksanakan perbuatan hukum sebagaimana sertipikat pada umumnya, termasuk lelang.

Usai waktu 30 (tiga puluh) hari sebagaimana yang diberikan oleh Kantor Pertanahan Kota Bandar Lampung berakhir, Pemohon belum menyerahkan sita jaminan dari pengadilan untuk memblokir sertipikat, sehingga berdasarkan aturan hukum, maka tanah akan kembali ke kondisi semula, sehingga boleh dilakukan perbuatan hukum apapun terhadap tanah yang bersangkutan, termasuk lelang.

Lelang dilaksanakan dengan asas kehati-hatian, setelah masa 30 (tiga puluh) hari pencatatan di buku tanah berakhir. Mengenai obyek lelang yang sedang diblokir di Kantor Pertanahan, tidak lantas menghentikan proses dilaksanakannya lelang.

Negara bisa dipandang memiliki kedudukan yang kecil dan remeh apabila setiap blokir membatalkan lelang. KPKNL menghormati prosedur blokir yang dilaksanakan di Kantor Pertanahan, akan tetapi tidak semua blokir dapat membatalkan lelang. Siapa saja bisa memblokir sertipikat jika ia

\footnotetext{
32 Wawancara dengan Badarudin Umar, Kepala Seksi Hak Tanah dan Pendaftaran Tanah Kantor Pertanahan Kota Bandar Lampung, 18 Agustus 2016, Pukul 13.10 WIB.

${ }^{33}$ Soeparmono, R. (2006). Masalah Sita Jaminan (C.B) Dalam Hukum Acara Perdata. Bandung: Mandar Maju, p. 3-5.

${ }^{34}$ Mertokusumo, Sudikno. (1998). Hukum Acara Perdata di Indonesia. Yogyakarta: Liberty, p. $48-58$.
} 
merasa berkepentingan, namun akan ditelaah pula apakah ada kepentingan lain yang lebih besar dari kepentingan Pemohon blokir. ${ }^{35}$

Kepala Kantor Pertanahan hanya boleh menolak berkas permohonan apabila dokumen persyaratan, yang diajukan ke Kantor Pertanahan tidak lengkap. ${ }^{36}$ Jika setelah dipelajari ternyata prosedur perolehan hak sesuai hukum, dan berkas-berkas persyaratan peralihan hak sudah lengkap, maka peralihan hak wajib untuk dlaksanakan.

Bentuk perlindungan hukum bagi pembeli lelang adalah jaminan kepastian hukum kepemilikan tanah dengan cara pendaftaran peralihan hak atas tanah/ balik nama lelang di Kantor Pertanahan. Seperti telah dijelaskan di atas, bahwa pendaftaran tanah diselenggarakan untuk menjamin kepastian hukum.

Hal ini sejalan dengan asas aman pendaftaran tanah yang diatur dalam Pasal 2 PP No. 24 Tahun 1997 dan Penjelasannya bahwa pendaftaran tanah di Indonesia dilaksanakan dengan maksud untuk menunjukkan, bahwa pendaftaran tanah perlu diselenggarakan secara teliti dan cermat sehingga hasilnya dapat menjamin kepastian hukum sesuai tujuan pendaftaran tanah itu sendiri.

Setelah seluruh persyaratan balik nama tersebut dilengkapi, Kantor Pertanahan Kota Bandar Lampung selaku instansi pemerintah yang bergerak di bidang pelayanan pertanahan tidak boleh menolak menerima berkas permohonan peralihan hak tersebut.

\section{Penutup}

\section{Kesimpulan}

Setelah melakukan penelitian, maka dapat ditarik beberapa simpulan, antara lain:

a. Peralihan hak atas tanah yang diperoleh dari lelang berdasarkan hak mendahulu negara, yang dilakukan oleh Kantor Pertanahan Kota Bandar Lampung adalah sah sebab telah memenuhi syarat-syarat formal lelang.

b. KPP Pratama Tanjung Karang dan KPKNL dalam melaksanakan lelang tanah untuk pelunasan utang pajak telah sesuai dengan ketentuan Pasal 32 ayat (2) UU KUP, Pasal 97 ayat (3) dan (4) UU PT, serta syarat formal lelang, sehingga perlindungan hukumnya ialah dibebaskan dari segala tuntutan hukum. Bentuk perlindungan hukum bagi pembeli lelang adalah jaminan kepastian hukum kepemilikan tanah melalui pendaftaran peralihan hak atas tanah/ balik nama di Kantor Pertanahan.

\footnotetext{
${ }^{35}$ Wawancara dengan dengan Andri Dwinanto, Kepala Seksi Lelang KPKNL Kota Bandar Lampung Tanggal 5 Agustus 2016 Pukul 15.00 WIB.

${ }^{36}$ Pasal 6 ayat (3) Peraturan Kepala Badan Pertanahan Nasional Republik Indonesia No. 1 Tahun 2010 Tentang Standar Pelayanan dan Pengaturan Pertanahan.
} 


\section{Saran}

a. Hak mendahulu negara adalah suatu sarana penting bagi negara untuk menjamin terpenuhinya kewajiban-kewajiban untuk memikul beban perpajakan. Hal ini karena kas negara harus mempunyai kepastian untuk mendapatkan penghasilannya, dan tidak dapat membiarkan begitu saja anasir-anasir yang tidak bertanggung jawab, yang tidak mau menunaikan kewajibannya dalam bersama-sama memikul beban pemerintah. Mengingat pentingnya hak mendahulu negara dalam penyelenggaraan tertib administrasi perpajakan, perlu adanya peraturan yang lebih mendetail mengenai hak ini, mengingat hak ini hanya diatur di dalam satu pasal baik di UU KUP dan UU PPSP.

b. Perlu penyuluhan mengenai kegiatan pertanahan, terutama mengenai pemblokiran sertipikat, sebab intensitas permohonan pengajuan pemblokiran termasuk sering terjadi, namun banyak masyarakat yang belum benar-benar mengerti mengenai blokir. Blokir sertipikat bisa mempunyai dampak yang besar karena dapat mengganggu hak dari pihak-pihak yang mempunyai kepentingan atas tanah, sehingga pemblokiran tidak dapat sembarang dilaksanakan. Pengajuan, pencabutan, kapan gugurnya blokir perlu diberikan pemahaman kepada masyarakat.

c. Hendaknya bagi masyarakat memiliki kesadaran bahwa pembayaran pajak adalah kewajiban, dimana bila tidak membayarnya akan mendapatkan konsekuensi, misalnya penyitaan harta penanggung pajak. Jika penyitaan dan pelelangan harta dilaksanakan sesuai dengan peraturan yang berlaku dan penanggung pajak memang terbukti beritikad buruk tidak membayar pajak, maka ia harus menerima konsekuensinya itu.

\section{Daftar Pustaka}

\section{A. Buku}

Ais, Chatamarrasjid. (2004). Penerobosan Cadar Perseroan dan Soal-Soal Aktual Hukum Perusahaan. Bandung: PT. Citra Aditya Bakti.

Fuady, Munir. (1996). Hukum Bisnis Dalam Teori dan Praktek, Buku Ketiga. Bandung: PT. Citra Aditya Bakti.

Harahap, M. Yahya. (2009). Hukum Perseroan Terbatas. Jakarta: Sinar Grafika.

Harsono, Boedi. (2008). Hukum Agraria Indonesia: Sejarah Pembentukan Undang-Undang Pokok Agraria, Isi dan Pelaksanaannya. Jakarta: Djambatan.

Ilyas, Wirawan B. dan Burton, Richard. (2007). Hukum Pajak Edisi 3. Jakarta: Salemba Empat. 
Kurniawan. (2014). Hukum Perusahaan Karakteristik Badan Usaha Berbadan Hukum dan Tidak Berbadan Hukum di Indonesia. Yogyakarta: Genta Publishing.

Limbong, Bernhard. (2014). Politik Pertanahan. Jakarta: Margaretha Pustaka.

Marsyahrul, Tony. (2005). Pengantar Perpajakan. Jakarta: PT. Gramedia Widiasarana Indonesia.

Mertokusumo, Sudikno. (1998). Hukum Acara Perdata di Indonesia. Yogyakarta: Liberty.

Nurmantu, Safri. (2005). Pengantar Perpajakan. Jakarta: Granit.

Soemitro, Rochmat. (1998). Asas dan Dasar Perpajakan 2. Bandung: PT. Refika Aditama.

Soeparmono, R. (2006). Masalah Sita Jaminan (C.B) Dalam Hukum Acara Perdata. Bandung: Mandar Maju.

Subekti. (2001). Pokok-Pokok Hukum Perdata. Jakarta: PT. Intermasa.

Sumarja, FX. (2010). Hukum Pendaftaran Tanah. Bandar Lampung: Universitas Lampung.

Sutedi, Adrian. (2014). Peralihan Hak Atas Tanah. Jakarta: Sinar Grafika. . (2013). Hukum Pajak. Jakarta: PT. Sinar Grafika.

Zarqoni, Mohammad Machfudh. (2015). Hak Atas Tanah. Jakarta: PT. Prestasi Pustakaraya.

\section{B. Jurnal}

Khairandy, Ridwan. (2007). Perseroan Terbatas Sebagai Badan Hukum; Jurnal Hukum Bisnis. Vol. 26: 5.

Kurniawan. (2014). "Tanggung Jawab Pemegang Saham Perseroan Terbatas Menurut Hukum Positif”. Jurnal Hukum Mimbar Hukum. 26(1): 8081.

Sjahdeini, Sutan Remy. (2001). "Tanggung Jawab Pribadi Direksi dan Komisaris". Jurnal Hukum Bisnis. Vol. 14: 100.

\section{Peraturan Perundang-Undangan}

Undang-Undang No. 19 Tahun 2000 Tentang Perubahan Atas UndangUndang No. 19 Tahun 1997 Tentang Penagihan Pajak Dengan Surat Paksa

Undang-Undang No. 40 Tahun 2007 tentang Perseroan Terbatas

Undang-Undang No. 28 Tahun 2007 tentang Perubahan Ketiga atas UndangUndang No. 6 Tahun 1983 tentang Ketentuan Umum dan Tata Cara Perpajakan

Undang-Undang No. 14 Tahun 2015 tentang Anggaran Pendapatan dan Belanja Negara Tahun Anggaran 2016

Peraturan Pemerintah 24 Tahun 1997 tentang Pendaftaran Tanah 
Peraturan Kepala Badan Pertanahan Nasional Republik Indonesia No. 1 Tahun 2010 Tentang Standar Pelayanan dan Pengaturan Pertanahan PMK. 27/PMK.06/2016

PMNA/KBPN No. 3 Tahun 1997 